\title{
Ecclesia Reformata semper Reformanda: A convergent approach to science and theology may reinforce Scriptural authority
}

\author{
Author: \\ André C. Pieterse ${ }^{1}$ \\ Affiliation: \\ ${ }^{1}$ Department of Dogmatics, \\ University of the Free State, \\ South Africa

\section{Correspondence to:} \\ André Pieterse \\ Email: \\ apieterse@ngkrokodilrivier. \\ co.za \\ Postal address: \\ Posbus 318, Brits 0250, \\ South Africa \\ Dates: \\ Received: 03 Feb. 2015 \\ Accepted: 09 June 2015 \\ Published: 20 Aug. 2015 \\ How to cite this article: \\ Pieterse, A.C., 2015, \\ 'Ecclesia Reformata semper \\ Reformanda: A convergent \\ approach to science and \\ theology may reinforce \\ Scriptural authority', Verbum \\ et Ecclesia 36(1), Art. \#1420, \\ 12 pages. http://dx.doi. \\ org/10.4102/ve.v36i1.1420

\section{Copyright:} \\ (C) 2015. The Authors. \\ Licensee: AOSIS \\ OpenJournals. This work is \\ licensed under the Creative \\ Commons Attribution \\ License.
}

Read online:

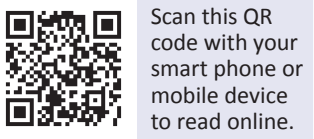

The purpose of this article is to debate the relationship between a convergent approach to the sciences and Scriptural authority. The thesis is that a multi-disciplinary convergent methodology may be beneficial in the current apologetical debate about the relevance of Scripture. This line of thought is also in compliance with the ideals of the protestant reformation. We will assess this view by investigating the possible consonance between scientific perspectives and theological confessions of what it means to be human. Subsequently the focus will shift to the impact consonance might have on the different interpretations of the creation narratives in Genesis. In conclusion, we will state the case for a convergent approach to the sciences, and the benefits with regard to Scriptural authority.

Intradisciplinary and/or interdisciplinary implications: This study would not have been possible without extensive intradisciplinary and interdisciplinary research. The subject matter imposes on the researcher the necessity to make use of knowledge from across the theological spectrum. It compels the various subjects within the theological encyclopedia to take note of any new research and incorporate it. In addition, it dispels the myth that natural science and theology have little in common. From a holistic perspective on creation the need for continuous interaction between the sciences is imperative.

\section{Introduction}

You may ask the question: why yet another article on the subject matter relating to science and theology. In order to clarify the important issues surrounding the entangled nature of both subjects to one another, as well as their mutual relationship to other philosophies, scholars publish countless articles, books and essays. The reason for this article is very specific. The title commits this paper to the Reformation's slogan of continuously transforming one's life, thoughts and being to God's Word. A convergent methodology to the sciences encourages this commitment, and refocuses one's vision on the transforming nature of Scripture, but on a multi-disciplinary level.

In the apologetical debate between the sciences there is one topic that surfaces regularly: the authority or perceived authority of Scripture. From a Christian point of view, the Word is the foundation out of which all further discussion grows. Unfortunately, theologically, as well as scientifically, the precise nature of this foundation is challenged. What does Scriptural authority mean? The answer to this question sometimes leads to different subjective responses. The author, as a believer in the triune God, understands Scripture as God's revelation of himself to the world. This revelation encompasses more than mere spiritual issues. Scripture also speaks with authority regarding the nature and purpose of the physical universe. Although believers may differ on the precise understanding of different physical events, it is still possible to accept the Bible as God's authoritative Word concerning physical and cosmological proceedings. Sadly this status is regularly disputed in the dynamic debate between science and theology.

How does the discussion between the sciences relate to Scriptural authority? Generally, there is a direct relation between the type of theology or belief that engages with the sciences and this questioning of authority. For example, if one follows a fundamentalist ${ }^{1}$ approach, it may close the door on any further dialogue, whereas a liberal ${ }^{2}$ point of view may degrade Scriptural authority into insignificance.

The purpose of this article is to highlight the possibility that science and theology may not only coincide peacefully, but that a convergent approach between the sciences are beneficial to

1.The definition of this term may depend on the relevant context. In this context, it describes a consistent literal interpretation of Scripture without regard for the literary constraints of the different texts.

2.Liberal in this sense engages with Scripture as if it was no different from any other ancient text. Divine inspiration is not considered. 
both, especially regarding the nature of Scriptural authority. It is important to underline this statement, because a hermeneutical circle connects these two aspects. For example, if one views science and religion as two opposing forces only connected by conflict ${ }^{3}$, it is usually the result of a very limited understanding of the authoritative scope of Scripture, or of the theories of science that is seen as factual.

Likewise, if one has a limited view of the authority of Scripture, it necessarily leads to the conflict opinion. The premise of this article is that a convergent approach to the sciences directly affects one's understanding of Scriptural authority. Convergence emphasises the Reformation's principle of allowing the Word to transform society in accordance to God's revelation. Furthermore, it draws the attention to the cosmological significance of Christ as confirmed in Colossians 1.

What is the theological significance of this article? Traditionally ${ }^{4}$ any complimentary or convergent approach to the sciences is under suspicion of liberal ideas not conducive to reformed theology. For example, in his article, Geloofswetenschap (Kennis en leven, 1922), Bavinck (1922:1) wrestles with the scientific status of reformed theology. He highlights the common conception regarding theology and science in his era, a dualism with a definite rift between the sciences $^{5}$. This approach eventually leads to conflict, as well as a limited function of Scripture as evident in the current dialogue $^{6}$. A convergent approach to the sciences has the opposite effect. It may assist contemporary reformed theology in countering the growing influence of fundamentalist creationist models ${ }^{7}$. In addition, it may reconstitute Scripture to its rightful place within the current dialogue.

Why is it necessary to confirm Scriptural authority? In his insightful article, The authority of Scripture and the triune God (2011), Paddison (2011:450) reminds us that present issues regarding the authority of Scripture are related to broader social concerns where the nature of authority in general is being questioned. In a world where science and technology makes the impossible possible, authors such as Richard Dawkins claim that biblical faith is 'blind', as opposed to scientific facts that can be scientifically validated (Dawkins 2006). In his latest publication, Science and faith, a new introduction (2012), John Haught (2012:12) analyses the work of influential authors such as, Dawkins, Christopher Hitchens, Peter W. Adkins and Daniel Dennet, and shows

3.This term presupposes that science and religion are from an epistemological leve incompatible.

4.This phrase requires caution because of its sensitivity to context. In this case, it describes the regular outlook to natural theology from certain reformed points of view.

5.Contemporary Reformed theology progressed to a more accommodating stance towards natural science, for example, Standpunt van die Moderamen van die Algemene Sinode, 2009, Kerk en wetenskap, Carmelite: Junie 23, 4. However, in a post-modern society there is a constant threat to withdraw to the safety of this dualism

6.This phenomenon is not limited to a Reformed view of the Bible. The Pentecostal movement also grapples with this dilemma. See Yong (2011).

7.See, Creationism (2013). convincingly that not science, but scientism8 leads to the degradation of Scriptural authority amongst the scientific community. In addition, certain contextual and liberation theologies plead for a revision of the validity of Scriptural evidence, in an attempt to be more inclusive (Paddison 2011:452). It is clear that from an apologetical point of view a fresh attitude is needed. Paddison's argument for a closer relationship between Scriptural authority and the Trinity is extremely helpful in this regard, especially when considering a complimentary approach to the sciences. Paddison (2011) notes that:

... the action of the triune God is the necessary condition for a relational account of authority, remembering that by locating Scripture in the space of God this beckons us to locate Scripture in the space of the world. (p. 455)

It is within this space that we testify about God's agency in and through Jesus Christ as revealed through Scripture, and his continuing transformation of the cosmos.

It is important to note that ever since the Reformation, in contrast to a Roman Catholic understanding, there are categorical differences between the authority given to Scripture, confession, and theology. Potgieter (1990:57) reminds us to differentiate between norma normans (the normative character of Scripture regarding God's revelation) and norma normata (the derivative character of confessions, in regard to Scriptural authority). Theology, in contrast, is the temporal response of the church/believers concerning God's revelation through Scripture (and nature?). In the debate on Scriptural authority one should acknowledge these differences. There is always the risk that church dogma, which is inherently bound to time and context, will get the same emphasis as Scripture in the discussion with the sciences.

In order to reinforce Scripture's authority in the debate you need a more inclusive methodology.

One possibility to a more comprehensive outlook towards the sciences is a complementary viewpoint. Polkinghorne (2008) defines his approach as complementary:

Science is looking at one aspect of the world ... how things happen, what is the process of the world? Religion is asking a deeper question - is there a meaning and purpose behind what is happening? Is there a divine will - a mind behind what is happening? (p. 1)

The theological benefits of this methodology regarding Scriptural authority may be a rediscovery of the realisation that Scripture has a more distinct focus. Although this method respects the integrity of the sciences, it may end in contrast (see Barbour 1990:10) to one another. A complimentary style should be refined even further, in order to be cosmologically sufficient. John Haught (2012) chooses the term 'convergence':

A convergent approach concurs with the contrast method that religious faith and natural science are two distinct ways

8.Scientism describes a mindset which believes that science is the only reliable road to the truth. Paradoxically, this statement is unscientific. 
of understanding the world, but it acknowledges that they inevitably interact. It proposes that scientific data can broaden the scope of Scriptural understanding. Likewise, Biblical faith could deepen the meaning of scientific discoveries. (pp. 4-5)

This approach could be beneficial in reinforcing Scriptural authority. A convergent line of thought could serve as a tool to argue for a specific multi-disciplinary approach in the debate between science and theology.

The title of this paper highlights the entrenched belief that, from a reformed theological perspective, there always should be the desire and will to conform back to the true meaning and focus of Scripture through the illumination of God's Holy Spirit. One should not abandon this aspiration in the discussion between the sciences.

This article will present the argument concerning Scriptural authority within the current scientific dialogue in the following manner. We will apply this thesis to the problem of human uniqueness as researched and debated from a scientific point of view, as well as the Biblical testimony of what it means to be human. The proposal is that the subject matter concerning the origins of humanity and relevance in creation provide the backdrop to argue for a convergent approach to the sciences, which in turn will reinforce Scriptural authority within the on-going debate. Consequently, it is necessary to discuss concisely the difference between certain interpretations of Genesis. This line of thought is essential. It will serve as a Scriptural vantage point in the debate, which in turn will integrate seemingly diverse topics. In conclusion, we will state the need for a multi-disciplinary approach to the sciences and outline the benefits it may have for Scriptural authority.

\section{The quest for human uniqueness}

Are human beings unique in creation? If so, what constitutes this exclusive status? From a theological and Christian point of view, the exegesis of certain Biblical texts usually provides the correct answer. Van Selms (1984:36) argues that human beings, created in God's image (Gn 1:26, 27) are special, because God endowed and established them as rulers over creation. To be human means to be a shadowy effigy of the Creator.

Unfortunately, the current debate is not so straightforward. The present search for human uniqueness may, or may not have any theological motive. It is deeply rooted in scientific exploration and philosophical rhetoric concerning the status of humanity. Scientific data and faithful Biblical confession about the reality of being human frequently confronts and challenges one another. Fortunately, conflict is not the only way forward if one takes interdisciplinary research seriously. A convergent approach is possible.

For example, in his research, Van Huyssteen integrates both anthropological evidence from early hominids, as well as text-critical data from ancient texts in his reflection on what it means to be human. His (Van Huyssteen 2005) conclusion is that:

The theologian, therefore, needs to be aware that Genesis 1 texts are meant as clear expressions of the uniqueness of the primal human being, who occupies a position between the deity and humanity, and who is the only one who can lay claim to this distinction. (pp. 106, 121)

One might ask what primal human being means in this context, as well as its place between the deity and humanity. Van Huyssteen is not clear on this matter. What is clear is that Scriptural authority continues to be important for him. In addition, the importance to engage with the broader scientific community becomes crucial for the on-going apologetical debate. This type of methodology confronts an exclusive theological mind-set with the possibility of a complementary approach. The truth is any serious biblical scholar cannot simply ignore scientific data about early man. What type of scientific data are we talking about? - It is true that scientific data are always open to scrutiny as new 'evidence' comes forward and new hypotheses are formulated. However, in the apologetical debate it is necessary to accept certain data as factual until more probable evidence surfaces. The scientific data referred to in this case are the 'factual evidence' from mainstream anthropology, paleo-anthropology and other disciplines as acknowledged by the current scientific fraternity relating to early hominoids and their physical and cultural development, for example, the cave paintings in Lascaux, and the possibility to interpret them as informative on certain aspects of human development and uniqueness. Empirical data from the natural sciences is beyond the traditional focal point(s) of Scripture. Although such data, for example, as portrayed in the book and DVD with the same title, Journey of the Universe (Swimme \& Tucker 2011) are regularly described from a purely scientific worldview without any inclination to religious beliefs, it still serves as a vantage point for further dialogue and poses serious questions to believers.

What then is theology's response to scientific hypothesis? Unfortunately the only reply is often one of ignorance and conflict. But, the choice in doing so may reside theology in future to the pastime of individuals with no interest in reality. Is this remark valid? A Christian scientist might take exception because his life's work focuses primarily in making reality more comprehensible. The key to understanding from a theological viewpoint is the concept of consonance. If a Christian theologian/scientist confesses that the triune God is indeed the Creator and sustainer of all creation (as revealed in Scripture), and that the initial commandment of God in Genesis 1:28 implied being culturally creative, as well as responsibly investigating the richness of the created order, then there has to be a certain consonance between the theological analysis of the Biblical text and sound scientific data regarding the state of the created order. The God from the text is also the temporal agent actively engaging in reality. Polkinghorne (1996:73) states: 'Theological discourse on the doctrine of creation must be consonant with that account 
(science's story about the history of the world'. The type of scientific engagement Polkinghorne refers to is obviously responsible scientific endeavours rooted in recognised scientific principles. In addition, the principle of consonance in creation could be linked to Article 12 of the Confessio Belgica (1561) (The Belgic Confession) where the unity and diversity in creation are confessed - Pieterse (2010:261).

Unfortunately, if one simply dismisses science from the debate there are even more severe theological implications. From a theological point of view, it confines man's purpose and focus in nature only to the spiritual/biblical aspect, as if culture and history is of no importance. Jesus engaged with the culture and wisdom in his day. Luke 2:41-52 testifies about Jesus as an 8 year old in discussion with the leaders in the synagogue. His conversation with the Samaritan woman in John 4 clearly indicates how Jesus understood and applied the different cultures of his day to conduct his message. In addition, the testimony of the apologists in the first centuries was significant because they understood the arguments from within their social context. In the significant article about the post-apostolic churches relationship to government and society, Berry (2007:54) highlights how early Christians interacted with, confessed to, and dealt with the inconsistencies of a non-Christian society.

If then one takes science seriously, what does it tell us about early man? In the next few paragraphs, the author would like to give a glimpse of the present research, and demonstrate how it may be beneficial to a theological confession.

It is appropriate to give the author's opinion on the concept of evolution before we start. The on-going debate about the various factors regarding the possibility of evolutionary processes in the world encompasses a myriad of facets, and the theory of evolution is regularly misused in theological debates to prove or disprove personal beliefs. It is also true that the idea of evolution (as generic term) is frequently critiqued, often from within the scientific community. Nevertheless, the reality of evolutionary processes at work presently in the world cannot be denied. Lennox $(2007: 98,99)$ is correct when he says that the dispute over evolution is frequently confused by failure to recognise that the term is used in several different ways. He identifies at least five different definitions of evolution for example, change, development, variation; micro-evolution; macro-evolution; molecular evolution et cetera. In the debate between the sciences the use of the term evolution is often only associated with Darwin's theory of evolution, as well as the subsequent denunciation of God as the Creator. Fortunately, it is not the only option. In his book, Seven days that divide the world: the beginning according to Genesis and science (2011), Lennox proposes that it is possible to read the different creation accounts in Scripture without dismissing modern scientific knowledge. Padilla (2015:1) highlights this analysis of Hebrew semantics in his presentation of a complex creation account within 24 hour days, as well as his argument that any evolutionary development regarding Adam and Eve should be dismissed.
The creation of man had to be the result of supernatural intervention (Lennox 2011:74). His argument, although sound in certain aspects, is not beyond critical assessment. Lennox's methodology naturally leads to certain questions, for example, was it the original intention of the author(s) of the creation narratives in Genesis to convey that creation literally took place within periods of 24 hours, or was it purely synonymous with the creation accounts of the period and which the Israelites came to know. Heyns (1988:99) chose the term historical-prophetic information to underline the fact that the creation narratives are primarily a doxology of the triune God, as opposed to the idols Israel came to know in Babel. As already stated, even the early church fathers had certain reservations against a purely literal interpretation. Therefore, is Lennox's line of thought the only option in the struggle between text and empirical data? The author believes that another possibility might be the acknowledgement that from the beginning of creation God was actively at work in the creative process, for example, through his use of secondary causes (of which evolutionary processes and certain physical events in the cosmos are options), and in his time, through his action ${ }^{9}$ man came into being. Although the proposal of secondary causes are only but one of the options in the ongoing debate about God's agency in the world, and is not excused from valid criticism, it serves in this context as a credible possibility. God's possible utilisation of secondary causes in the creative process is one of the conclusions Farley (1988:235) puts forward from a reformed perspective.

In the quest for human uniqueness, it is very tempting to limit oneself to the very select path of the natural sciences. In his book, Darwin's dangerous idea (1995), Dawkins pursues this path with great enthusiasm. He concludes that all forms of complexity in nature derive from evolutionary processes with no regard for any type of design or designer (Dawkins 1995:317). Although popular, this perspective is prone to reductionism ${ }^{10}$ and it fails to incorporate this richness of non-physical systems in nature. Therefore, an interdisciplinary approach may be more productive. Scholars from various disciplines began to realise that the questions about human uniqueness have to incorporate all the physical and non-physical aspects of nature.

King (2008:454) defines human religious imagination as a unique attribute to the species. It has deep evolutionary roots, not determined by evolution, but rather enabled by it. Van Huyssteen echoes this relationship between evolution and religious consciousness $(2010: 347,8)$. Although this link neither proves nor disproves the existence of God - an argument (Lennox 2007) Dawkins became famous for - it confronts believers with the possibility that '... evolutionary processes endowed us with a genetic predisposition for ultimate questions'. A convergent attitude will embrace this possibility as not in conflict with the creation narratives.

9.The debate about God's agency in the world is of a complex nature and the subject of various studies for example, the Divine action project (1988-2003). This article has not the scope to unpack the various possibilities and difficulties.

10.Although Murphy (2010:245) makes a distinction between methodological and epistemological reductionism, the expression defines all natural processe exclusively to the sumtotal of the different physical attributes found in nature. 
King employs results from current biological anthropological research on the behaviour of primates in her reflections on Van Huyssteen's book, Alone in the world? (2006). Although she states clearly that it is not her intension to discern direct continuity between ape behaviour and human religious consciousness (King 2008:455), she claims that behaviour of primates in the wild reflects evolved capacities for empathy, meaning-making and consciousness. Her train of thought is clear. To understand primate development one has to incorporate the complex interactions of different physical and non-physical aspects over the space of time. Does it have any significance for a theological reflection on human uniqueness? King (2008:458) concludes that the process of becoming human (as with the development of the great apes) was gradual and depended on evolved processes. It is necessary to state that the analogy in this context has no intention to debate or promote any possible direct lineage between primates and modern humans. It only highlights the fact that in both instances certain traits in primates and humans depended on the evolution of time, irrespective of origins. Harlow (2010:192) underlines the importance of these processes by relating suffering, selfishness, and death to human faculties such as novelty, complexity and freedom. God may well have commandeered this type of development in order to create.

What then does it mean to be human from a scientific or philosophical point of view? Van Huyssteen $(2005: 111,112)$ identifies language as one of the cornerstones necessary for the progressive development of humanity into a complex species ${ }^{11}$. Without the ability to communicate, effectively any new technical or social innovation would have been difficult. Strauss $(2012: 280,281)$ also recognise the pivotal role of language in human development, but he argues that the irreducible complex interaction between the mouth, larynx, and brain in speech makes it improbable that a causal evolutionary explanation is the only way to explain the origin of language.

It is not possible to separate the ability to communicate effectively from the dawn of consciousness ${ }^{12}$ in human beings. This capacity of (self)-awareness may be another unique feature that makes us human. The problem from a paleoanthropologist point of view relates to the nature of the evidence presented in pre-history regarding a possible time frame for human cognition. Van Huyssteen (2005:106, 108) illuminates this dilemma by highlighting the connection between consciousness and aesthetic appreciation in the Paleolithic period. He argues that the ability of for example, Cro-Magnon people ${ }^{13}$ to produce art underlines the possible presence of consciousness, although the current definition of artistic endeavour does not necessarily correlate with the

11.Van Huyssteen supports his argument on the research done by: Donald (1991) Mellars (1990); Diamond (1998).

12.It is not within the scope of this article to debate the different aspects relating to the evolution of human (self) - awareness. This important subject demands a separate study.

13.It refers to the Paleolithic cave paintings in South West France and the Basque Country painted toward the end of the last Ice Age, for example, Lascaux. original ancient understanding or purpose. He believes that this capacity to imagine and transfer these symbolic creations in a visual and audible manner defines the early presence of consciousness. This evidence from pre-history, although debatable, might be supportive for a present day definition of human theological relevance (Van Huyssteen 2010:344). It may also illuminate the authoritative nature of Scriptural confession by the acknowledgement from the scientific community that natural science cannot exclusively declare what it means to be human.

For example, the entangled nature of language and consciousness cannot be separated from another uniquely human feature: religious awareness. It is clear that any theological examination into the character of this attribute has to incorporate a multi- disciplinary approach. Therefore, the prehistoric imagery in the 'cave-art' of France and Spain might be helpful for the religious observer. Van Huyssteen (2010:341) incorporates research from the social sciences (Potts 2004) to interpret this ancient symbolism and argues that, although symbolism may assist in the development of language, in this case it may be the product of language. Symbolic language became the vehicle to describe non-physical experiences and beliefs. For the present observer it gives insight into the ancient religious imagination. It is important to note that this recognition of the spiritual is not only an esoteric faculty of the human mind ${ }^{14}$ (Van Huyssteen 2005:109).

It is noteworthy that Collins ${ }^{15}$ (2010:155) as a respected scientist deduces from the current evidence at hand that being human from a scientific point of view contains certain parallels with textual evidence found in Scripture. The creation narratives in Genesis reveal a God who created as a conscious Person and communicated religious values to man. In the process of creation, man received these attributes as a creation within God's image.

To comprehend this progression of becoming human one has to look further than merely the possession of certain individual characteristics. To grasp human uniqueness a holistic viewpoint is essential. Van Huyssteen (2005:108) chose the term 'embodiment'. This term describes how our sexuality and embodied moral awareness correlate directly to our embodied self-transcendence as creatures who are predisposed to religious belief. The image of God is not limited to intellectual or spiritual capacity. Rather:

... the image is the human, and for this reason Imago Dei can only be read as imitatio Dei: to be created in God's image means we should act like God, and so attain holiness. (Van Huyssteen 2005:122)

This perspective is beyond the usual reformed understanding of being created in God's image. Holiness is usually accepted

14.It is a popular argument from a reductionist scientific point of view, for example, Laughlin (1997:471-488).

15.Francis Sellers Collins (born April 14, 1950), is an American physician-geneticist noted for his discoveries of disease genes and his leadership of the Human Genome Project (HGP). He currently serves as Director of the National Institutes of Health in Bethesda, Maryland. 
as an attribute we receive in conjunction with our relationship to Christ, and not something we could receive through acts of righteousness. Then again, Scripture makes it quite clear (e.g. 1 Peter 1:16) that holiness is also reinforced through man's activity in the world, only possible because there is a relationship with God. Van Huyssteen's assessment only highlights one aspect of Imago Dei. Notwithstanding these differences, the connection between self-awareness and knowledge of God is clear. Spykman (1992:199) states as a commentary on Calvyn's thoughts (1957:1.1.2), 'True selfknowledge stimulates us to knowledge of God'. It becomes clear that a reductionist scientific viewpoint on human uniqueness may not be sufficient.

Since Watson and Crick (Heredity 2008) proposed in 1953 their now famous model of the double helix DNA, the temptation grew to explain human beings simply in terms of the genetic code. In his work, God's undertaker: Has science buried God? (2007), Lennox disputes this tendency. He argues that the number of genes are simply too few to account for the incredible complexity of inherited characteristics, as well as the differences between species (Lennox 2007:131). It is a view Ostling (2011:25) also states. Although one can trace human rationality along evolutionary processes, it is by no means the sole proprietor of knowledge. Van Huyssteen (2010) uses the study of evolutionary epistemology to explain:

that cognition is a process that is not to be described as an endless, accumulative chain of adaptations building on one certain foundation, rather as a complex interactive process in which we move beyond our biological roots without ever losing touch with them. (p. 339)

It simply means that biology and culture have a mutual evolutionary history.

How does the relevant scientific research into human uniqueness assist us in the acknowledgement of Biblical authority? Scientific inquiry makes it clear that we live in a complex world. The evolution of the different attributes that were identified (e.g. language, self-consciousness, religious awareness) provides only one piece in the quest for human uniqueness. One cannot reduce human consciousness merely to a chain of causal biological processes. To appreciate creation you need a more inclusive tool. Haught $(2012: 82,83)$ employs the concept of a 'layered explanation'. It means that everything in our experience is subject to more than one level of understanding and that the different levels need not compete or contradict one another. For example, this page exists because of, (1) the invention of the printing press, (2) the author is trying to convey certain ideas, (3) and these ideas were published in a book. None of the levels competes with one another; rather they concede that understanding requires a holistic approach. Equally, Scripture as Gods Word to creation is authoritative in the quest for human uniqueness. A Biblical confession transcends and enriches a purely reductionist declaration of what it means to be human. Conversely, the quest for human uniqueness is an on-going process incorporating different disciplines.
Specialised fields of study (e.g. paleo-anthropology) may enrich the readers' understanding of the text. The reformed belief of sacra scriptura sui ipsius interpres is not challenged, because it is not the intention of Scripture to give exclusively modern scientific facts about human uniqueness (Heyns 1988:26). Gunton (1998:183) acknoweledges the progression in creation when he remarks: '... we should understand creation dynamically as a project. The perfection of beginning is not the perfection of the completed, but of that which is to be perfected'. The aim of the previous paragraphs was to illuminate the milieu in which the current debate about the nature of Scriptural authority takes place and to present an alternative. The following paragraphs will focus specifically on certain possibilities to interpret the creation narratives in Genesis, bearing in mind that some scientific data may have been previously unavailable.

\section{The creation accounts in Genesis in respect of scientific data}

The scientific quest to describe what it means to be human, and the biblical narrative about the creation of man in the first chapters of Genesis should exhibit certain parallels, and not exclude one another. Although the tendency from both theology and natural science may be suspicion towards each other's credentials and motives, a convergent approach may be beneficial to both sciences. This method could restore the recognition of Scriptural authority within previously hostile environments. The aim of the next few paragraphs is to highlight the possibility that the first chapters of Genesis were not meant to give an exact account of the historical development of man or creation, but had a much deeper message. A convergent approach would free scientific endeavour to potentially fill in the detail about creation, and be beneficial to the interpretation of the original text.

One of the consequences of the information age is that previously exclusive scientific data, for example, about the possible origins of early man, is now being shared and comparedbyordinary peopletotraditionalbeliefsand dogmas. The discerning theologian cannot escape this questions about, and comparisons with the biblical text. In addition, these processes also influence the different exegetical models of the creation accounts in the first chapters of Genesis. In the important book, Reading Genesis after Darwin Oberly (2009:6, 7) reminds us that this interpretational dilemma is not unique to the post-Enlightenment era. In the third century, Origen also grappled with the dilemmas of a strictly literal reading of the text. One of the first questions when reading the creation accounts in Genesis regard historicity. Was it the authors' intension to convey literally an exact historical account (7 days of 24 hours) of creation, as well as the precise method God used to create man? In answering this question several important aspects have to be considered.

For example, Collins (2010:149) differentiates between four possible interpretations on the historicity of the Genesis account: (1) '"Straight" history', with a minimum of figurative 
language, (2) the author was talking about what he thought were actual events, using rhetorical and literary techniques to shape the readers' attitudes toward those events, (3) the author intended to recount an imaginary history, using recognisable literary conventions to convey 'timeless truths' about God and humans and (4) the author told a story without even caring whether the events were real or imagined, his main goal was to convey various theological and moral truths.

It is vital that a conscious choice by the investigator, as to the nature of the Genesis account, precedes any inquiry into a possible convergent approach to the sciences. The analysis of the creation narratives in Genesis becomes even more complex when, even to the casual reader, it is clear that the creation accounts in the first two chapters have a completely different makeup and outlook ${ }^{16}$. Harlow (2010:185) underlines this discrepancy by showing that Genesis 1 portrays God as creating an unspecified number of male and female human beings at the same time - after land animals, on day 6 of its seven-day schema. Genesis 2, by contrast, pictures Yahweh God creating one man, then animals, and then one woman on the only day of creation it envisions. This inconsistency in the literal text may be the link that could benefit a convergent approach to the sciences, and ultimately illuminate the nature of Scriptural authority. It seems, according to Collins's model, that 'straight history' could possibly be eliminated as the original intention of the author(s). More than one account of the same creative event certainly has an additional purpose other than a mere historical reconstruction of what took place. Buitendach (2012:5) reminds us of St Augustine's perspective that there is a causal relationship between the two creation narratives, the created potential of creation in chapter 1 leads to actuality.

During the exegetical process to determine the meaning of the creation narratives in Genesis there is another issue that research cannot ignore. The creation accounts in Genesis, if compared to other ancient near eastern myths, contain certain parallel descriptions with these non-biblical texts. Blenkinsopp (2004:93-95) compared the similarities between the stories of Enkidu and Shamhat in the Gilgamesh epic from Mesopotamia ( $\pm 1800 \mathrm{BC}$ ) and the Adam/Eve narrative as found in Scripture. The resemblance in story line and sequence of events are compelling and poses a challenge to the recognition of Scriptural authority within certain environments.

Collins (2010:150,151) and Collins (2006:242) recognises these similarities, but defends Scriptural authority by pointing out that the ancient myths created a literary backdrop against which the Genesis stories were written. The function of Genesis $1-11$ is:

... to provide the true pre- and proto-history of the Bible's alternative worldview story, whose 'purpose is to shape Israel's view of God, the world, and mankind, and their place in it all'. Collins (2010:150, 151)

16.Fohrer $(1968: 146,178)$ clarifies the difference in focus by unraveling the original source strata of the text. Genesis $1: 1-2: 4$ a was originally part of the priestly document $(\mathrm{P})$, whereas Genesis 2:4-3:24 was part of the Jahwist $(\mathrm{J})$ material. Although the documentary hypothesis is still influential, other more recent Although the documentary hypothesis is still influential, other more recent \& Harten 2009:49)
Although one cannot describe the first chapters of Genesis as straight history, it has a historical core and a defined theological focal point.

Harlow $(2010: 181,182)$ clarifies this phenomenon when he highlights the differences between ancient texts and the biblical creation account. Whereas myths usually collapse a timeless past into the present, the author(s) of Genesis place these events within a temporal framework. In addition, the Genesis version makes several pointed theological assertions, for example, the sovereignty of one God and the acknowledgement of the sun and moon as part of creation, and not as gods. It is clear that the biblical narrative integrated ancient texts with a revelatory experience of God, an encounter where God inspired the writer to document not, '... prepositional revelation, but narrative theology' (Harlow 2010:185). In the epic work, Genesis: World of myths and patriarchs (1996), this hypothesis is further developed. Feyerick, Gordon and Sarna (1996:50) state that, '[i]n order to develop their beliefs, the Hebrews borrowed some Mesopotamian themes, but adapted them to the unique conception of their one God'. McKeown (2008:12-14) in his commentary on Genesis reveals how the creation stories in Genesis and the Babylonian creation myth of Enuma Elish have much in common, but also how the authors of Scripture transformed this myth to highlight the work of the One true Creator of heaven and earth. A convergent approach acknowledges Gods supremacy over creation and his utilisation of these established concepts in the ancient world for revelatory purposes. In this way the Israelites could draw a definite distinction between the accepted idols and myths of other nations and the revelation of the one triune God, Creator and sustainer of all creation.

How does this connection to ancient stories relate to the faith of the believer and the confession of Scriptural authority? First of all, if you read the first chapters of Genesis from a purely literal point of view and you take everything in the Genesis story as straight history ${ }^{17}$; it may be detrimental to faith. The reason is that, in the apologetic debate (where the motive should be to explain faith based on Gods revelation in Scripture) these 'coincidences' cannot be accounted for by simply concluding that the other person has a lack of faith in Gods providence. These uncomplicated answers often lead to a disrespect of Scripture and faith, especially if the other person is sincere in his motives and knowledgeable about scientific endeavour. Secondly, it rejects the notion that Scripture is composed of different literary types, each of which should be read accordingly. If the faithful acknowledge the biblical narrative as part of Gods provisional caring throughout human history, it connects the biblical stories with world history and may enhance faith. Believers sometimes struggle to connect Scripture with the real world, and more often than not, the Bible is relegated only to spiritual matters and the authoritative nature of Scripture is diminished. The possibility that the writer(s) of

17.It refers to an account of past events with the sole purpose of communicating as objectively as possible, precisely in a literal fashion, how it happened. 
the different creation accounts illuminated ancient myths through divine inspiration should not have a negative effect on Scriptural authority. In the New Testament there are many examples where established beliefs are given a new meaning. For example, in Acts 1723-1734 Paul connects the Athenians belief in an unknown God to Faith in Christ. Through divine inspiration old beliefs are given a proper understanding. In reality, it may lead to a better awareness of the literary genre of Genesis and assist the casual reader to appreciate Gods revelation in world history, and not to get confused in thorny issues, for example, if Adam and Eve were truly the first and only people, or where did Set get a wife?

Who then decides what history is and what are thorny issues? First of all, it is important to remember what form of history Genesis wants to convey. In his assessment of the historicity of Scripture Heyns $(1988: 25,26)$ reminds us that the authors frequently used facts that are selective, interpreted, combined, and kerugmatic in nature. The type of history Scripture wants to express is not historical-chronological and one-dimensional in character, but prophetic history with a soteriological edge. Brueggemann $(2002: 95,96)$ states that the term history is more complex than we like to admit. He distinguishes between remembered history, actual history, and confessed history. To align the creation narratives in Genesis only to actual history may diminish the intention of Scripture, and have a negative impact on the extent of Scriptural authority. When reading the first chapters of Genesis, a syntactic and semantic assessment of the text could contribute in establishing what style of literature we are dealing with. Does this mean that the accounts in Genesis are not true history? No! It is a testimony about the agency of God throughout human history, from the creation of man to the eschatological promises in waiting. It is however not complete history! A convergent approach accepts that modern scientific methods, amidst valid critique, may have the capacity to assist in filling in certain details.

It is not the focus of this article to debate the historicity of Adam and Eve, yet any analyses of the Genesis accounts cannot escape this potentially hazardous issue. I will limit myself to a few remarks. If we accept, as the author certainly does, that the narrative about Adam and Eve is more than mere a symbolical acknowledgement about the origin of man, and we agree that it articulates an actual event where God actively created people in his image, then we have no choice but to try and set these events chronologically on a historical timescale. But, is it even possible to date proto-history? A workable alternative might be found in the scientific hypotheses about early man. If for example attributes such as self-consciousness, language, and esthetic appreciation are recognised as typically human, then it might be possible to speculate, but with the sole purpose of moving the apologetical debate between the sciences forward. Scripture assigns similar attributes to man, but it seems that they only exist because man was created in God's image. The question is: could God's creation of man coincided with this awakening of modern humans? What does Scripture say? It is clear that the Bible speaks about Adam and Eve as real people (e.g. Paul's comparison between Christ and Adam in Romans 5). However, it is noticeable that the first intention of the Genesis narrative was not to give precise detail about the first humans. If this was the case, contradictions in the text and storyline would be limited. In addition, if Genesis is read in conjunction with the rest of the Pentateuch and Scripture certain theological motives come to the fore, the least of which is explicit detail about early man. The tendency in the current apologetic (Dawkins 1986) debate is to hold Scriptural authority at ransom with regard to an opinion on Adam and Eve. However, is it fair? Does Scriptural authority depend on Adam being literally the first and only human, or is it possible that Adam could have been part of a larger group, previously created by God in an unspecified manner (e.g. through secondary causes, agential, etc.). Could the narratives in Genesis 1:27; 2:7 then refer to a supernatural act whereby man became human (with all the attributes associated with being human from a scientific point of view) only when God re-created him in his image through the breath of Life? This obviously leads to Scriptural and temporal implications. From a scientific point of view it might have coincided with the first evidence of self-consciousness, aesthetic appreciation, etc. Biblical commentators differ in their assessment of these passages. In their commentary on Genesis, Jamieson-FaussetBrown acknowledges a link between the Biblical account of man being created from the dust of the earth, and scientific evidence about the atomic properties of the human body. They state about the breath of life:

... this phrase is used to show that man's life originated in a different way from his body-being implanted directly by God (Ec 12:7), and hence in the new creation of the soul Christ breathed on His disciples (Jn 20:22). (http:/ / bibleapps.com/jfb / genesis/2.htm)

Could these creative acts have been separated by different time spans? Conversely, Keil and Delitzsch (n.d.) envision the creative act all in a single moment (Online:7). It is impossible to precisely reconstruct the manner in which events unfolded. Yet, in the apologetical debate with the sciences fresh hypotheses of a theological nature could be beneficial. This proposition serves as one example in the manner of which a convergent approach might benefit the rediscovery of Scriptural authority, especially within the debate between the sciences.

Furthermore, it is significant to note that the scientific definition and the theological understanding of what it means to be human are not always fully compatible. Whereas the sciences generally concentrate on anatomical advances, theologically the focus is primarily on the readers' understanding of being created in God's image. It is not possible to quantify scientifically the latter. The temptation is to integrate scientific data on a one to one basis with ancient texts. Collins (2010:158) highlights the foolishness of such attempts and advice against a literal interpretation of the Genesis material. For instance, the reference to farming and crafts in Genesis 4 may lead to the deduction that this piece of history took place during the 
Neolithic period. Then again, if the narratives in Genesis are viewed as more than mere evidence of the precise way man was created, certain parallels could emerge.

When the exegesis of the first chapters of Genesis considers modern scientific enquiry it becomes clear that one cannot speak of pure history. Harlow (2010:185), for example, argues that textual evidence supports this view. He refers to the use of the Hebrew term ha-'adam as a generic term not intended to specify anyone in particular, and the extensive use of genealogies in Scripture. A critical reader might suggest that from textual evidence (Gn 2:23) the 'generic term' ha -'adam seems to suggest a specific person, the first man, and Harlow's hypothesis does not stand up to scrutiny. This line of thought should not be problematic. If it was the author of Genesis' intension to state that the triune God revealed himself in the course of history to man, endowed man with his Spirit, and affirmed his covenant to man and creation, the use of ha-adam in a personal sense is normal. Adam was then indeed the first man, not literally, but the first man God revealed himself to. In addition, the function of genealogy in the Old and New Testaments, according to mainstream theology, is not to give a literal report of all the generations, but they have a deeper theological significance within different literary genres. Stannard (2012:13) also takes up this line of thought when, in his examination of the work of St Augustine, De Genesi ad Litteram, he concludes that even the church fathers did not accept a literal interpretation of Genesis. Literal in the sense of an exact account in minute detail of the precise methods God utilised in the creation of man. Genesis, as with the rest of Scripture, is part of a library consisting of different literary types, combined in one volume as the authoritative Word of God.

In conclusion, it became clear that the exegesis of the creation narratives in Scripture cannot escape the need to incorporate the data of different disciplines. In addition, if one purely reads the text literally, it leads to a myriad of theological and text-critical issues. A convergent approach respects the historicity, as well as the literary genre of the individual confessions. It accepts the need for faith and conveys it within the multi-disciplinary discussion.

\section{Towards a multi-disciplinary convergent approach}

Why is a multi-disciplinary approach necessary when theologians debate an essential issue such as Scriptural authority, especially concerning the details about early man? The first reaction to this question may be one of contempt. One of the reasons is the a-symmetrical nature between natural science and theology. John Polkinghorne, although a firm believer in a consonant relationship between the sciences, is the first to acknowledge their differences in methodology. He remarks:

They use different methods: in the one case (science), the experimental procedure of putting matters to the test, in the other (theology), the commitment of trust which must underlie all personal encounter, whether between ourselves, reality or God. (Polkinghorne 1990:n.p.)
This statement is true in a general sense, but the philosophy of science points out that on a certain level even natural science has to make the leap of faith. For example, in order for theoretical physicists to make predictions about the state of the universe, they have to assume that the influence of natural laws, as experienced on earth, is constant throughout the cosmos. Langdon Gilkey (1985:49-52) points out that, in his view, science promotes public knowledge, whereas the focus of theology is more on a personal and existential level.

Furthermore, one might feel that we should treat Scripture, as Gods revelatory Word in a very special way, beyond any other forms of knowledge. Although most believers would agree with this belief, not all of them may concur with what we mean by a special way. This opinion is especially true of readers that favour a more literal, even fundamentalist understanding of all the passages from the Bible. One might argue that Scripture is sufficient and the only information man needs regarding his origin. Any additional information may have a negative impact on the credibility of the Bible. It is vital to understand that the argument for a complementary convergent approach, especially when reflecting about the essence of early man, does not degrade Scriptural authority. Scripture is authoritative because God through his Holy Spirit revealed himself in the history of man in different ways. Paddison (2011:453) states, 'If Scripture is a living authority, it is first and foremost because the triune God works through it.' The Spirit communicates this revelation as trustworthy. A convergent approach will assist the reader in focusing on theological truths in the Word that God wants to convey, and free certain genres in Scripture from unfair expectations concerning historical facts and scientific accuracy. As stated in Paragraph 2, the reformed confession of sacra scriptura sui ipsius interpres is not challenged from a convergent point of view. It was never the intension of the Reformers to imply that Scripture's self-illumination is strictly tied to a consistent literal understanding of all the texts in the Bible. Take for example Calvin's interpretation of miracles in Scripture (Pieterse 2010).

What then do we mean by a complementary convergent approach? Böhr first used the term complementary in 1927 in describing the differences between quantum mechanics and classical physics (Reich 2003:150). From Reich's definition (2003:150) it becomes clear that one has to respect the uniqueness as well as the relationship between two entities. This characteristic enabled Polkinghorne to apply the term in his approach to the relationship between science and theology. He remarks, 'A belief in quantum theory, therefore, does not seem dissimilar to religious faith, dealing as it does with a belief in an unseen reality' Polkinghorne (2008:n.p.).

The complexity and interrelated nature of the different aspects of the created order lead Van Huyssteen (2006:650, 2010:330) to remark that an interdisciplinary approach should be a top priority for theologians seeking to be responsible agents in communicating Scriptural truths to a secular society. Any theological research and exegesis of the Genesis material 
concerning early man has much to benefit from the insights of paleo-anthropology, primatology, and archaeology. Does it mean that theology has to constantly revise classical doctrines, as Harlow (2010:192) suggests, to remain intellectually credible and culturally relevant? Definitely not! This method creates the impression that scientific knowledge is superior to other forms of knowledge and banishes theology to a process of deconstruction. A complementary convergent approach recognises the integrity of different kind's of knowledge and is mindful of the complexities of the epistemological process. This methodology accepts that natural science is based on hypotheses or theories that sometimes prove to be incorrect and in time replaced by new ones. Does this mean that the entire apologetical debate should be terminated? Absolutely not! Although all evolutionary principles cannot always, in every circumstance, be stated as factual, the debate between the sciences has to continue, as it might be mutually beneficial. In the debate between theology and natural science it is sometimes necessary to accept the concept of inference to the best explanation ${ }^{18}$ regarding scientific hypotheses and move forward.

In order for a convergent approach to be useful to Scriptural authority, one has to be aware of certain boundaries between the sciences. Holmes Rolston (1996:64) made it quite clear when he remarked, ' $[t]$ he religion that is married to science today is a widow tomorrow, while the religion that is divorced from science today leaves no offspring tomorrow.' The question about the extent of the boundaries between theology and natural science depends on the preconceived assumptions of the investigator on his ideal relationship between the sciences (Barbour 1990; Gilkey 1985). Nonetheless, if we pursue a convergent approach, it is possible to engage with one another despite differences. Polkinghorne (1990) acknowledges that science and religion use separate methods of understanding; yet they share common ground in terms of access to knowledge, and the hermeneutical circle (Polkinghorne 2004:37). Van Huyssteen (2006:663 and King 2008:464) highlights this common ground, especially concerning personhood and the emergence of early man. He makes use of the term relationality and argues that science and religion are intertwined due to their common base of rationality which evolved over time. Although it is possible to differentiate between different rationalities, certain tools ${ }^{19}$ enable the researcher to find common ground between the sciences.

Scientific hypotheses seek to discover when man became human. Scripture confesses who made us human. Are these two sentences related? They have to be. Polkinghorne (1996:73) utilises the term consonance to explain that faith

18.This concept originated in the philosophy of science and refers to the existence of two or more hypotheses and the inquiry into which of them explain a certain set of parameters/values, at this moment in time, in the most probable way. One of the pyrameters/values, at this moment in time, in the most probable way. One of the hypotheses is accepted, although it may be very difficult, sometimes impossible to prove its reliability beyond any doubt. Until a better option is available this explanation is the relevance given to the Big Bang hypothesis in cosmology.
hypothesis serves as a reference point. An example of inference to the best

19.Van Huyssteen $(2005: 104,105,108)$ calls for a post-foundationalist approach where transversal reasoning protects and clarifies the boundaries between the sciences. in a Creator God implies that religious consciousness and scientific endeavour does not exclude one another. Both are expressions within one creation.

Within a multi-disciplinary approach, it is possible to reveal tiny bits of what consonance may imply. Van Huyssteen (2005:122) makes the bold statement that the Imago Dei might have emerged from nature itself. He bases this audacious claim on the recent theological focus on the embodied nature of our human condition, which intersects with arguments about human uniqueness from paleo-anthropology. At the root of this argument is the concept of Gods agency. Did human self and religious consciousness emerge through Godgiven natural processes, or was it the product of a singular supernatural act? It is significant that Heyns (1988:134) also connects self-consciousness with the Imago Dei. Human self-consciousness is an important stepping-stone towards a senses divinitatis and the realisation that human beings have a special connection with God. Spykman (1992:199) states as commentary on Calvyn's thoughts (1957:1.1.2), 'True self-knowledge stimulates us to knowledge of God'. God's interaction with man does not exclude natural processes.

The phrase embodiment might assist us in understanding this synergy. In Colossians 2:9, 10, Paul writes: 'For the full content of divine nature lives in Christ, in his humanity $(\sigma \omega \mu \alpha \tau 1 \kappa \omega \varsigma)$, and you have been given full life in union with him' (Good News edition, 1991). Lohse (1986:100) points out that the use of the word 'bodily' indicates that this Godly indwelling is real. But, the real meaning and fullness of this reality only becomes clear when a person belongs to Christ in whom the entire fullness of the deity dwells. Although science and religion may differ on the exact method the Imago Dei came to be, it is clear from a Scriptural perspective that all men were created in God's image, but only through a real personal connection to Christ this image is perfected.

In his most recent publication, Een lichtkring om het kruis. Scheppingsleer in christologisch perspectief (2014), the celebrated Dutch theologian Prof. A van de Beek debates this relationship between Christ and creation. He states:

Het is niet zo dat we het eers over het kruis kunnen spreken en vervolgens zelfstandig over de schepping. We kunnen over de schepping alleen spreken in het paradigma van het kruis. (Van de Beek 2014:14)

Christ and creation was connected from the very beginning. In Van de Beek's view, creation (including man as Imago Dei) was always in need of a cross; actually creation came to be with the very intension of the cross! This is one example of the manner in which theology could bridge the gap between the exegesis of Scripture and the creation narratives explored by natural science.

Embodiment emphasises that religious consciousness in humans cannot be exiled to a spiritual dimension alone. Van Huyssteen $(2010: 329,343)$ highlights that the key to true relational communication can be found in the embodied 
self where the human mind, linguistic, aesthetic, moral and religious dispositions are firmly embedded in our human bodies. This non-reductionistic notion may benefit theology by underlining a more nuanced perspective on human uniqueness, as opposed to a more abstract tendency. Furthermore, from an exegetical and hermeneutical point of view, embodiment challenges theology to understand Scripture on a much broader and deeper level. In addition, by acknowledging that science can make an important contribution to the quest for human uniqueness, Scriptural authority will be reinforced. It occurs when the reader appreciates that there are definite similarities between Biblical testimony about what it means to be human and external scientific data. Although faith is not based on, or the product of scientific knowledge, the biblical text is suddenly transported from an ancient testimony to a present day reality enforced by the revelation of the Holy Spirit. Does this line of thought relegate theological labour to a dependence on more superior scientific knowledge? Definitely not! A multi-disciplinary approach accepts the sovereign nature of each discipline, and the benefits of cooperation.

This attitude concedes that God is indeed Lord of all. Responsible scientific labour ${ }^{20}$ illuminates and assists the believer in appreciating and understanding certain aspects of a creation that God formed through his primary revelation, the Word that became man. The Word, of which Paul reminds his readers in Colossians 1, is also the cosmic Christ. Although Scripture, through the illuminating work of the Holy Spirit, is God's primary revelation, the believer recognises that the Bible has a limited goal and focus. In Psalm 148 the psalmist states, 'Praise the Lord from the earth; praise Him, hills and mountains; praise Him, sun and moon; praise Him, shining stars ...' (Holy Bible 1991). A multi-disciplinary approach may assist believers in grasping the wonders of creation in a way that the psalmist never could imagine. Glory be to God!

\section{Conclusion}

Ecclesia Reformata semper reformanda - Does a convergent approach do justice to this important Reformation slogan? In addition, could this methodology persuade non-believers to take the confession of Scriptural authority by believers as a sincere expression of faith that could enhance scientific enterprise? The previous paragraphs were an attempt to clarify these questions.

It became clear that science and theology are allies and that each discipline contributes to the understanding of very specific aspects of the created order. As complementaries to one another they highlight the richness and entangled nature of creation. From a Scriptural point of view this multidisciplinary approach is very important. Why? Firstly, it reinforces the belief that Scripture, as Gods revelatory Word to man, has definite spiritual goals. Any attempt to seek

20.It describes a scientific endeavor that accepts the limits of natural science and its hypothetical nature. It is aware of the pitfalls of reductionism and value the contribution of other disciplines. answers of a scientific nature about the state of the cosmos from biblical testimony is not only an abuse of the text, but a degradation of Scriptural authority within an apologetical discourse. Vice versa: if one believes that natural science offers unlimited knowledge about every part of creation (as scientism and scientific imperialism suggest), even on matters of a spiritual nature, it is disrespectful to responsible scientific labour, and unfaithful to the philosophical foundations of true science.

Secondly, a convergent methodology reinforces the classical conviction that Scriptural authority is not based on external sources, but stems from God's own revelation as found in 2 Timothy 3:16. This attitude towards the sciences is beneficial in dismissing creationist efforts of recreating certain Biblical scenarios (e.g. the crossing of the Red Sea in Exodus 14) in an attempt of scientifically proving that this event was possible (Creationism 2003). These endeavours ultimately centre Scriptural authority on the positive outcome of scientific labour. Scientific hypotheses could never be the foundation of Faith in the triune God. A convergent approach recognises the agency of God throughout human history. This agency incorporates natural and supernatural events.

Thirdly, responsible scientific labour sets Bilblical testimony firmly within world history. Scripture, as an authoritative text speaks not only to certain groups on the margins of society, but gives meaning to the human race.

\section{Acknowledgements Competing interests}

The author declares that he has no financial or personal relationships which may have inappropriately influenced him in writing this article.

\section{References}

Algemene Sinode Nederduits Gereformeerde Kerk, Moderamen, 2009, Kerk en wetenskap, Carmelite, Junie 23, 4.

Barbour, I.G., 1990, Religion in the age of science, SCM Press, London.

Bavinck, H., 1922, Kennis en leven, J.H. Kok, Kampen.

Berry, C.E., 2007, 'How the post-apostolic church responded to government: Gleaning public dos and don'ts from the second-century apologists', Criswell Theological Review Fall 5(1), 53-67.

Blenkinsopp, J., 2004, Treasures old and new: Essays in the theology of the Pentateug, Eerdmans, Grand Rapids, MI.

Brueggemann, W., 2002, Reverberations of faith: A theological handbook of Old Testament themes, John Knox Press, Westminster.

Buitendach, J., 2012, 'Is die ortodoksie se verstaan van die sondeval belemmerend vir die gesprek tussen teologie en natuurwetenskap?', In die Skriflig/In luce verbi 46(1), Art. \#41, 10 pages. http://dx.doi.org/10.4102/ids.v46i1.41

Calvyn, J., 1957, Institutes, vol. 1, transl. H. Beveridge, .Eerdmans, Grand Rapids, MI.

Collins, C.J. 2006, Genesis 1-4: A linguistic, literary and theological commentary, P\&R Publishing, Phillipsburg, NJ.

Collins, C.J., 2010, 'Adam and Eve as historical people, and why it matters', Perspectives on Science and Christian Faith 62, Sept (3), 147-165.

Creationism, 2003, Stanford Encyclopedia of Philosophy, viewed 11 June 2013, from http://plato.stanford.edu/entries/creationism/

Dawkins, R., 1986, The blind watchmaker, Norton, New York, NY.

Dawkins, R., 1995, Darwin's dangerous idea, Simon \& Schuster, New York, NY.

Dawkins, R., 2006, The God delusion, Houghton Mifflin, New York, NY.

Donald, M., 1991, Origins of the modern mind: Three stages in the evolution of culture and cognition, Harvard University Press, Cambridge. 
Diamond, J., 1998, Guns, germs and steel, Vintage/Random House, London.

Farley, B.W., 1988, The providence of God, Baker Book House, Grand Rapids, MI.

Feyerick, A., Gordon, C.H. \& Sarna, N.M. (eds.), 1996, Genesis: World of myths and patriarchs, New York University Press, New York, NY.

Fohrer, G., 1968, Introduction to the Old Testament, 7th edn., transl. D. Green, Society for Promoting Christian Knowledge, London.

Gilkey, I., 1985, Creationism on trial, Winston Press, Minneapolis, MN.

Gunton, C.E., 1998, The triune creator: A historical and systematic study, Eerdmans, Grand Rapids, MI.

Harlow, D.C., 2010, 'After Adam: Reading Genesis in an age of evolutionary science', Perspectives on science and Christian faith 62, Sept (3), 179-195.

Haught, J.F., 2012, Science and faith: A new introduction, Paulist Press, New York/ Mahwah, NJ.

Heredity, 2008, Encyclopaedia Britannica Deluxe Edition, Encyclopædia Britannica, Chicago, IL.

Heyns, J.A., 1988, Dogmatiek, NG Kerk Boekhandel, Pretoria.

Holy Bible, 1991, Good news edition, National Book Printers, Goodwood.

Jamieson, R., Fausset, A.R. \& Brown, D., 'Genesis 2: Bible Commentary', viewed 23 July 2014, from http://bibleapps.com/jfb/genesis/2.htm

Jenson, R.W., 2001, Systematic theology, vol. 2, The works of God, Oxford University Press, New York, NY.

Keil \& Delitzsch OT Commentary, n.d., Genesis 2:7, viewed 23 July 2014, from http:// bibleapps.com/kad/genesis/2.htm

King, B.J., 2008, 'Reflections on Wentzel van Huyssteen's “Alone in the world?"', Zygon 43(2), 451-466. http://dx.doi.org/10.1111/j.1467-9744.2008.00927.x

Kugler, R. \& Harten, P., 2009, An introduction to the Bible, Eerdmans, Grand Rapids, MI.

Laughlin, C.D., 1997, 'The cycle of meaning: Some methodological implications of biogenetic structural theory', in S.D. Glazier (ed.), Anthropology of religion: of handbook, pp. 471-488, Greenwood, Westport, 472 .

Lennox, J.C., 2007, God's undertaker: Has science buried God? Lion Hudson, Oxford.

Lennox, J.C., 2011, Seven days that divide the world: The beginning according to Genesis and science, Zondervan, Grand Rapids, MI.

Lohse, E., 1986, Colossians and Philemon, 4th edn., Fortress Press, Philadelphia.

McKeown, J., 2008, Genesis: The two horizons Old Testament commentary, Eerdmans, Grand Rapids, MI.

Mellars, P. (ed.), 1990. The emergence of modern humans, Edinburgh University Press, Edinburgh.

Murphy, N., 2010, 'Divine action, emergence and scientific explanation', in P. Harrison (ed.), The Cambridge companion to science and religion, pp. 244-259, University Press, Cambridge. http://dx.doi.org/10.1017/CCOL9780521885386.013

Oberly, W., 2009, 'How should one read the early chapters of Genesis?', in S.C. Barton \& D. Wilkinson (eds.), Reading Genesis after Darwin, pp. 6-7, Oxford University Press, New York, NY. http://dx.doi.org/10.1093/acprof:oso/9780195383355.003.0001

Ostling, R.N., 2011, 'The search for the historical Adam', Christianity Today (June), $23-27$.
Padilla, B., 2015, 'The Harvard Ichthus. Review of "Seven days that divide the world"', viewed 25 June 2014, from http://augustinecollective.org/augustine/a-review-ofviewn-lennoxs-seven-days-that-divide-the-world

Paddison, A., 2011, 'The authority of Scripture and the triune God', International Journal of Systematic Theology 13(October), 448-462.

Pieterse, A.C., 2010, 'Die God-wêreld-verhouding in die kontemporêre geloofwetenskap- dialoog: Die bydrae van J.C. Polkighorne', D.Th-proefskrif in die Department van Dogmatologie, Universiteit van die Vrystaat.

Polkinghorne, J.C., 1990, 'God's action in the world', viewed 21 February 2008, from http://www.starcourse.org/jcp/Polkinghorne.html

Polkinghorne, J.C., 1996, The faith of a physicist, Fortress Press, Princeton.

Polkinghorne, J.C., 2004, Science and the trinity: The Christian encounter with reality, Yale University Press: Durham, NC.

Polkinghorne, J.C., 2008, God and science, viewed 02 July 2008, from http://www. christianevidencesociety.org.uk/index.asp

Potgieter, P.C., 1990, Skrif, dogma, \& verkondiging, Nasionale Boedrukkery, Kaapstad.

Potts, R., 2004, 'Sociality and the concept of culture in human origins', in R.W. Sussman \& A.R. Chapman (ed.), The origins and nature of sociality, n.p., Walter de Gruyter, New York, NY.

Reich, K.H., 2003, 'Complementarity', in J.W. van Huyssteen (ed.), Encyclopedia of science and religion, vol. 1, pp. 150-151, Macmillan, New York, NY.

Rolston III, H., 1996, 'Science, religion, and the future', in W.M. Richardson \& W.J. Wildman (eds.), Religion and science, pp. 62-81, Routledge, New York, NY.

Spykman, G.J., 1992, Reformational theology: A new paradigm for doing dogmatics, Eerdmans, Grand Rapids, MI.

Stannard, R., 2012, Science and belief the big issues, Lion Hudson, Oxford.

Strauss, D.F.M., 2012, 'A non-reductionist perspective on animals and humans', Journal for Christian Scholarship 49(3-4), 251-287.

Swimme, B.T. \& Tucker, M.E., 2011, Journey of the universe, Yale University Press, New Haven, NC.

The Belgic Confession, viewed 27 March 2013, from http://www.creeds.net/belgic/ main.htm\#14

Van de Beek, A., 2014, Een lichtkring om het kruis. Scheppingsleer in christologisch perspectief, Uitgeverij meinema, Zoetemeer.

Van Huyssteen, J.W., 2005, 'Human origins and religious awareness in search of human uniqueness', Studia Theologica 59, 104-128. http://dx.doi. org/10.1080/00393380500339586

Van Huyssteen, J.W., 2006, Alone in the world? Human uniqueness in science and theology, Eerdmans, Grand Rapids, MI.

Van Huyssteen, J.W., 2010, 'When were we persons? Why hominid evolution holds the key to embodied personhood', Neue Zeitschrift für systematische Theologie und Religionsphilosophie 52(s), 329-349.

Van Selms, A., 1984, De prediking van het oude testament, genesis, 4th edn., Uitgeverij Callenbach, Nijkerk.

Von Rad, G., 1965, Old testament theology vol. 2, Harper and Row Publishers, Edinburgh.

Yong, A., 2011, The spirit of creation, Eerdmans, Grand Rapids, MI. 